\title{
ANALISIS PENGARUH UKURAN PERUSAHAAN, PROFITABILITAS DAN UKURAN DEWAN DIREKSI TERHADAP PENGUNGKAPAN TANGGUNG JAWAB SOSIAL PERUSAHAAN (STUDI KASUS PADA PERUSAHAAN MAKANAN DAN MINUMAN DI INDONESIA)
}

\author{
Kartika Dewi Sri Susilowati, Triesti Candrawati, Aang Afandi \\ Politeknik Negeri Malang \\ kartika.dewi@polinema.ac.id
}

\begin{abstract}
Abstrak:Tujuan dari penelitian ini adalah untuk menguji pengaruh ukuran perusahaan, profitabilitas dan ukuran dewan direksi pada pengungkapan tanggung jawab sosial perusahaan. Sampel sejumlah 17 perusahaan makanan dan minuman yang terdaftar di Bursa Efek Indonesia selama periode tahun 2014 dan 2015 dengan kriteria selalu mempublikasikan laporan keuangannya, selalu melaporkan kegiatan tanggung jawab sosial perusahaan dan selalu memiliki keuntungan selama periode observasi. Dengan menggunakan analisis Partial Least Square (PLS) menggunakan PLS Smart Software, hasilnya menunjukkan pengaruh yang signifikan dari Ukuran terhadap CSR. Dengan nilai koefisien jalur sebesar 0,292 dan positif, dapat dikatakan semakin besar ukuran perusahaan semakin tinggi pula CSR. Analisis juga menunjukkan bahwa ada pengaruh positif yang signifikan antara ROA pada CSR. Dengan nilai koefisien jalur positif sebesar 0,471, dapat diartikan bahwa peningkatan ROA juga akan meningkatkan CSR. Begitu juga sebaliknya, jika ROA rendah, maka akan menyebabkan CSR ikut menurun. Di sisi lain, tidak ada pengaruh yang signifikan antara jumlah Direksi terhadap CSR. Dengan nilai positif dari koefisien jalur untuk 0162, dapat diartikan bahwa peningkatan dalam ukuran Dewan Direksi juga akan meningkatkan CSR. Analisis PLS juga menunjukkan bahwa ROA, Ukuran dan DK memiliki pengaruh pada CSR dengan daya prediksi keseluruhan model untuk 0,435, atau 43,5\%, sedangkan 56,5\% dipengaruhi oleh faktor atau variabel lain yang tidak termasuk dalam persamaan model.
\end{abstract}

\section{Kata Kunci:CSR, ROA, Direksi.}

Abstract:The purpose of this study was to examine the effect of firm size, profitability and size of the board of directors on the disclosure of corporate social responsibility. Sample are 17 food and beverage companies listed in Indonesia Stock Exchange during the period of 2014 and 2015 were selected using criteria always publish their financial reports, always reporting on the activities of corporate social responsibility and always had profits during the observation period. By using analysis Partial Least Square (PLS) with PLS Smart Software, the result shows a significant effect of SIZE to the CSR.With the path coefficient value of 0.292 and is positive, it can be said that the increase in SIZE (the size of the company) the higher will be the CSR. The analysis also showed that there is a significant positive effect between ROA on CSR. With the value of the positive path coefficients of 0,471, can be interpreted that an increase in ROA will also improve the CSR. And vice versa, if ROA is low, it will cause the CSR participate decline. On the other hand, there is no significant effect between the number of Board of Directors toward the CSR. With the positive value of path coefficients for 0162, it can be interpreted that an increase in the Board of Directors will also improve CSR. PLS analysis also shows that ROA, SIZE and DK have an influence on CSR with overall 
predictive power of the model for 0,435 , or $43.5 \%$, while $56.5 \%$ are influenced by other factors or variables that are not included in the model equations.

\section{Keywords: CSR, ROA, Board of Directors.}

\section{Pendahuluan}

Pelaksanaan tanggung jawab sosial perusahaan (Corporate Social Responsibility) di Indonesia saat ini bukan lagi bersifat sukarela, melainkan bersifat wajib terutama bagi perusahaan yang bidang usahanya terkait dengan sumber daya alam. Hal ini tertuang dalam pasal 74 Undang-Undang Nomor 40 Tahun 2007 tentang Perseroan Terbatas (UU PT), yang disahkan pada 20 Juli 2007. Dengan adanya Undang-Undang ini, perseroaan terbatas yang bergerak di bidang dan atau berkaitan dengan sumber daya alam harus melaksanakan tanggung jawab sosialnya kepada masyarakat. Bagi perusahaan yang melanggar kewajiban pelaksanaan Corporate Social Responsibility (CSR), sanksi pidana juga telah diatur dalam Undang-Undang Nomor 23 Tahun 1997 tentang Pengelolaan Lingkungan Hidup (UUPLH) Pasal 41 ayat (1) yang menyatakan: "Barangsiapa yang melawan hukum dengan sengaja melakukan perbuatan yang mengakibatkan pencemaran dan/ atau perusakan lingkungan hidup, diancam dengan pidana penjara paling lama sepuluh tahun dan denda paling banyak lima ratus juta rupiah" (Sutopoyudo, 2009).

Tanggung Jawab Sosial Perusahaan (CSR) sering dianggap inti dari etika bisnis, yang berarti bahwa perusahaan tidak hanya dihadapkan pada tanggung jawab yang berpijak pada single bottom line, yaitu nilai perusahaan (corporate value) yang direfleksikan dalam kinerja keuangannya (financial) saja, tetapi juga memiliki kewajiban terhadap pihak-pihak lain yang berkepentingan (stakeholder), termasuk didalamnya adalah pelanggan, karyawan, masyarakat sekitar, investor, pemerintah, supplier bahkan juga kompetitor. Global Compact Initiative atau GRI (2002) menyebut ini sebagai Triple Bottom Lines yang terdiri dari 3 P (Profit, People, Planet). Di sini bottom lines lainnya selain finansial juga ada sosial dan lingkungan, karena kondisi keuangan saja tidak cukup menjamin nilai perusahaan tumbuh secara berkelanjutan (sustainable).

Banyak manfaat yang diperoleh perusahaan dengan pelaksanan CSR, antara lain perusahaan diminati investor, produk semakin disukai oleh konsumen dan citra perusahaan akan semakin baik sehingga loyalitas konsumen akan semakin tinggi. Loyalitas yang tinggi dari konsumen akan menjamin tingkat keberlangsungan perusahaan. Dengan meningkatnya loyalitas konsumen, maka penjualan perusahaan akan semakin membaik, dan tingkat profitabilitas perusahaan juga meningkat (Satyo,2005 dalam Sutopoyudo, 2009). Dengan demikian, CSR juga merupakan alat marketing bagi perusahaan bila itu dilaksanakan secara konsisten dan berkelanjutan. Agar supaya aktivitas sosial perusahaan banyak diketahui oleh publik (masyarakat) maka perusahaan perlu meningkatkan awareness dari masyarakat terhadap semua aktivitas sosial perusahaan melalui sarana publikasi yang tepat, baik di media sosial masyarakat, media massa maupun media komunikasi formal yang dikeluarkan perusahaan seperti di laporan tahunan perusahaan.

Penelitian terkait dengan pengungkapan informasi sosial sudah banyak dikembangkan oleh beberapa peneliti dengan hasil yang berbeda-beda. Penelitian yang dilakukan Syahrir dan Suhendra (2010) telah dilakukan untuk melihat pengaruh karakteristik perusahaan terhadap indeks pengungkapan (disclosure index). Hasil 
penelitian yang diperoleh menunjukkan variabel likuiditas, leverage, ukuran perusahaan, dan tipe kepemilikan perusahaan berpengaruh terhadap kelengkapan pengungkapan laporan tahunan, sementara variabel profitabilitas tidak berpengaruh terhadap kelengkapan pengungkapan laporan tahunan. Sementara penelitian yang dilakukan oleh Lusia (2007), menunjukkan bahwa besarnya laba mempengaruhi dana CSR yang berupa program kemitraan dan bina lingkungan ke masyarakat yang dilaksanakan.

Sedangkan penelitian ini akan melihat bagaimana pengaruh ukuran perusahaan dan profitabilitas terhadap pengungkapan corporate social responsibility dengan kepemilikan manajemen sebagai variabel intervening. Variabel kepemilikan manajemen digunakan dalam penelitian ini karena dalam proses pengambilan keputusan, pihak manajemenlah yang menentukan seberapa luas pengungkapan pertanggung jawaban sosial perusahaan, sehingga variabel ini digunakan untuk menguji pengaruhnya di dalam hubungan corporate social responsibility dan ukuran serta keuntungan perusahaan. Selanjutnya, profitabilitas sebagai variabel dependen digunakan dalam penelitian karena secara teoritis semakin tinggi tingkat profitabilitas yang dicapai perusahaan maka semakin kuat pula hubungan pengungkapan sosial perusahaan.

Perbedaan lain dengan penelitian sebelumnya adalah digunakannya standar Global Reporting Initiative (GRI) di dalam mengukur pengungkapan sosial di dalam penelitian ini. Periode penelitian yang digunakan yaitu dua tahun pengamatan (2014 dan 2015) sehingga hal ini juga memperbaiki keterbatasan penelitian terdahulu yang hanya menggunakan satu tahun periode dan tidak digunakannya standar GRI di dalam pengukuran pengungkapan informasi sosial. Alasan digunakannya standar GRI di dalam penelitian ini karena pengungkapan yang terdapat didalam GRI bersifat internasional dan dan bisa digunakan untuk berbagai macam sektor dan ukuran perusahaan.

\section{KAJIAN PUSTAKA}

\subsection{Corporate Social Responsibility (CSR)}

Menurut International Finance Corporation dalam (http://www.ekofeum.or.id/) "Corporate Social Responsibility is the commitment of businesses to contribute to sustainable economic development by working with employees, their families, the local community and society at large to improve their lives in ways that are good for business and for development". Corporate Social Responsibility (CSR) adalah sebuah pendekatan dimana perusahaan mengintegrasikan kepedulian sosial dalam operasi bisnis mereka dan dalam interaksi mereka dengan para pemangku kepentingan (stakeholders) berdasarkan prinsip kesukarelaan dan kemitraan (Nuryana, 2005 dalam Suharto, 2006).

CSR merupakan tuntutan atas pendapat yang menyatakan bahwa bisnis tak hanya beroperasi untuk kepentingan para pemegang saham (shareholders), tapi juga untuk kemaslahatan pihak stakeholders dalam praktik bisnis, yaitu para pekerja komunitas lokal, pemerintah, LSM, konsumen dan lingkungan. Oleh Global Compact Initiative dalam Nugroho (2007) ini disebut dengan Three Bottom Line, yang meliputi 3-P yaitu, Profit, Planet and People. Hendaknya bisnis jangan hanya berorientasi pada laba (profit) semata, tetapi harusnya mensejahterakan orang (people) dan menjaga lingkungan (planet). Bradshaw dalam Harahap (2002:360) mengemukakan ada 3 bentuk tanggung jawab sosial perusahaan meliputi:

1. Corporate Philantrophy, disini tanggung jawab perusahaan itu berada sebatas kedermawanan atau voluntir belum sampai pada tanggung jawabnya. Bentuk 
tanggung jawab ini biasanya merupakan kegiatan amal, sumbangan atau kegiatan lain yang mungkin saja tidak lansung berhubungan dengan kegiatan perusahaan.

2. Corporate Responsibility, disini kegiatan pertanggungjawaban itu sudah merupakan bagian dari tanggung jawab perusahaan biasanya karena ketentuan UU atau bagian dari kemauan atau kesediaan perusahaan.

3. Corporate Policy, disini tanggung jawab sosial perusahaan itu sudah merupakan bagian dari kebijakan perusahaan.

\subsection{Manfaat Corporate Social Responsibility}

Wibisono (2007) mengungkapkan beberapa keuntungan bagi perusahaan dengan menerapkan tanggung jawab sosial yaitu reward yang sifatnya finansial maupun reward yang non financial.

A. Reward finansial bagi perusahaan diantaranya berupa :

1) Menurunkan biaya operasional perusahaan. CSR merupakan inisiatif yang harus dilakukan perusahaan untuk menekan biaya operasional perusahaan tersebut.

2) Meningkatkan volume penjualan dan pangsa pasar

3) Menarik calon investor

4) Pertumbuhan nilai pasar yang signifikan

5) Membuat kesejahteraan karyawan menjadi lebih baik

6) Mencegah risiko dari dampak social

7) Mencegah risiko dari dampak alam

B. Reward non Finansial bagi perusahaan

Adapun reward non finansial yang dimaksud disini lebih kepada manfaat yang diterima perusahaan bukan dalam bentuk uang tetapi lebih kepada "reputasi perusahaan" di mata masyarakat sekitar. Ada 5 elemen yang membantu proses "memperkuat reputasi perusahaan", yaitu :
1) Kepercayaan
2) Kredibilitas
3) Responsibility
4) Akuntabilitas
5) Mengelola risiko bisnis secara lebih tanggap dan terperinci.

\subsection{Pengungkapan Tanggung Jawab Sosial Perusahaan}

Menurut Freedman dalam dalam Kuntari dan Sulistyani (2007), ada tiga pendekatan dalam pelaporan kinerja sosial, yaitu :

1. Pemeriksaan Sosial (Social Audit)

Pemeriksaan sosial mengukur dan melaporkan dampak ekonomi, sosial dan lingkungan dari program-program yang berorientasi sosial dari operasi-operasi yang dilakukan perusahaan. Pemeriksaan sosial dilakukan dengan membuat suatu daftar aktivitas-aktivitas perusahaan yang memiliki konsekuensi sosial, lalu auditor sosial akan mencoba mengestimasi dan mengukur dampak-dampak yang ditimbulkan oleh aktivitas-aktivitas tersebut.

2. Laporan Sosial (Social Report)

Pendekatan-pendekatan yang dapat dipakai oleh perusahaan untuk melaporkan aktivitas-aktivitas pertanggungjawaban sosialnya ini dirangkum oleh Dilley dan Weygandt menjadi empat kelompok sebagai berikut (Henry dan Murtanto, 2001 dalam Kuntari dan Sulistyani, 2007) : 


\section{a. Inventory Approach}

Perusahaan mengkompilasikan dan mengungkapkan sebuah daftar yang komprehensif dari aktivitas-aktivitas sosial perusahaan. Daftar ini harus memuat semua aktivitas sosial perusahaan baik yang bersifat positif maupun negatif.

b. Cost Approach

Perusahaan membuat daftar aktivitas-aktivitas sosial perusahaan dan mengungkapkan jumlah pengeluaran pada masing-masing aktivitas tersebut.

c. Program Management Approach

Perusahaan tidak hanya mengungkapkan aktivitas-aktivitas pertanggungjawaban sosial tetapi juga tujuan dari aktivitas tersebut serta hasil yang telah dicapai oleh perusahaan sesuai dengan tujuan yang telah ditetapkan itu.

d. Cost Benefit Approach

Perusahaan mengungkapkan aktivitas yang memiliki dampak sosialserta biaya dan manfaat dari aktivitas tersebut. Kesulitan dalam penggunaan pendekatan ini adalah adanya kesulitan dalam mengukurbiaya dan manfaat sosial yang diakibatkan oleh perusahaan terhadapmasyarakat.

3. Pengungkapan Sosial dalam Laporan Tahunan (Disclosure In Annual Report)

Pengungkapan sosial adalah pengungkapan informasi tentang aktivitasperusahaan yang berhubungan dengan lingkungan sosial perusahaan. Pengungkapan sosial dapat dilakukan melalui berbagai media antara lain laporan tahunan, laporan interim/laporan sementara, prospektus, pengumuman kepada bursa efek atau melalui media masa.

\subsection{Faktor yang mempengaruhi Corporate Social Responsibiliy}

Menurut Chatrine (2008), pada umumnya implementasi CSR di perusahaan dipengaruhi beberapa faktor, antara lain :

1. Komitmen pimpinan perusahaan

Perusahaan secara keseluruhan sebaiknya meyakini bahwa CSR merupakan investasi demi pertumbuhan dan keberlanjutan usaha. Dengan kata lain, CSR bukan lagi dilihat dari sentra biaya (cost center) melainkan sentra laba (profit center) di masa mendatang. Dengan demikian, kegiatan CSR harus disikapi sebagai bagian penting dalam perusahaan, dimana CSR jika disikapi secara strategis dapat digunakan untuk memperbaiki konteks kompetitif perusahaan yang berupa kualitas lingkungan bisnis tempat perusahaan beroperasi.

2. Ukuran dan Kematangan Perusahaan

Perusahaan besar dan mapan memiliki peran yang lebih besar untuk memberikan kontribusi daripada perusahaan kecil dan belum mapan. CSR adalah wujud kesadaran perusahaan yang merupakan bagian dari masyarakat, dimana sebaiknya antara perusahaandan masyarakat memiliki hubungan yang bersifat simbiosis mutualisme sehingga tercipta harmonisasi hubungan bahkan meningkatkan citra dan performa perusahaan.

3. Regulasi dan sistem perpajakan yang diatur oleh pemerintah

Regulasi dan penataan sistem pajak yang kacau akan memperkecil ketertarikan perusahaan untuk memberikan donasi dan sumbangan sosial kepada masyarakat. Peran aktif pemerintah sangat diperlukan sehingga perusahaan dapat menjadi penolong dalam mengatasi masalah sosial yang ada di negara ini. Bisa dipastikan pemerintah tidak akan sanggup mengatasi berbagai permasalahan sosial secara sepihak. Untuk itu, sekecil apapun kedermawanan yang diberikan oleh perusahaan akan sangat besar artinya bagi 
pemerintah maupun masyarakat. Jika sistem regulasi kondusif dan insentif pajak semakin besar diberikan akan lebih berpotensi dalam memberikan semangat pada perusahaan untuk berkontribusi pada masyarakat.

\section{METODE PENELITIAN}

\subsection{Desain Penelitian}

Metode penelitian yang digunakan adalah metode penelitian kausal komparatif yaitu kegiatan penelitian yang berusaha mencari informasi tentang mengapa terjadi hubungan sebab akibat dan peneliti berusaha melacak kembali hubungan tersebut. Jenis data yang digunakan dalam penelitian ini adalah data sekunder yang diperoleh dari www.icmd.com.

\subsection{Populasi dan Sampel}

Populasi dari penelitian ini adalah keseluruhan perusahaan makanan dan minuman yang terdaftar di BEIdengan periode penelitian tahun 2014-2015. Pemilihan sampel menggunakan metode purposive sampling dengan kriteria sebagai berikut:

1. Perusahaan makanan dan minuman yang terdaftar di BEI tahun $2014-2015$.

2. Menyediakan laporan tahunan lengkap selama tahun 2014-2015.

3. Menyediakan informasi tentang kegiatan CSR pada periode 2014-2015.

4. Memiliki data yang lengkap terkait dengan variabel-variabel yang diteliti.

\subsection{Definisi Operasional Variabel Penelitian}

Dalam penelitian ini terdapat 3 klasifikasi variabel :

\section{Variabel Independen}

Variabel independen adalah variabel yang mempengaruhi atau menjadi sebab perubahannya atau timbulnya variabel dependen (terikat) (Sugiyono, 2012:2). Variabel dependen dalam penelitian ini adalah Profitabilitas dan ukuran perusahaan.

a. Profitabilitas yang digunakan dalam penelitian ini adalah adalah Return on Assets (ROA) yang dapat dihitung dengan rumus sebagai berikut :

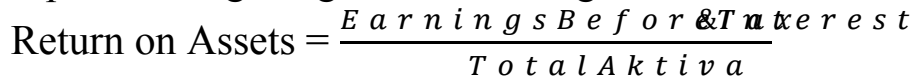

b. Ukuran Perusahaan

Ukuran perusahaan dalam penelitian ini adalah seberapa besar aset yang dimiliki oleh perusahaan yang diukur dengan menggunakan proksi total asset perusahaan. Rumus yang digunakan untuk menilai ukuran perusahaan sebagai berikut :

$$
\text { Size }=\log \text { (nilai buku total asset) }
$$

\section{c. Ukuran Dewan Direksi}

Variabel independen ketiga yang digunakan dalam penelitian ini adalah ukuran dewan komisaris yang mempengaruhi kebijakan perusahaan terkait dengan CSR. Sembiring (2005) menyatakan bahwa semakin besar jumlah anggota dewan komisaris, maka semakin mudah untuk mengendalikan CEO dan pengawasan yang dilakukan akan semakin efektif. Dikaitkan dengan pengungkapan tanggung jawab sosial perusahaan, maka tekanan terhadap manajemen juga akan semakin besar untuk mengungkapkannya (Beasly, 2000), sementara Nofandrilla (2008) menyatakan bahwa ukuran dewan komisaris tidak berpengaruh terhadap pengungkapan tanggung jawab sosial perusahaan. 


\section{Variabel Dependen}

Variabel dependen (variabel bebas) dalam penelitian ini adalah tingkat pengungkapan tanggung jawab sosial perusahaan (Corporate Social Responsibility). Tingkat pengungkapan CSR pada laporan tahunan perusahaan yang dinyatakan dalam Corporate Social Responsibility Index (CSRI) yang akan dinilai merupakan jumlah pengungkapan yang dilakukan perusahaan dengan yang disyaratkan oleh GRI yang berjumlah 78 item pengungkapan yang meliputi tema: economic, environment, labour practices, human rights, society, dan product responsibility. Rumus penghitungan Index luas pengungkapan CSR (CSRI) adalah sebagai berikut :

\section{Keterangan :}

$$
\operatorname{CSRIj}=\frac{\sum X i j}{n}
$$

$\mathrm{CSRIj}=$ Corporate social responsibility index perusahaan $\mathrm{j}$

$\Sigma \mathrm{Xij}=$ Jumlah item yang diungkapkan oleh perusahaan $\mathrm{j}$

$\mathrm{N}=$ Jumlah keseluruhan item, $\mathrm{n}=78$

Pengukuran indeks pengungkapan CSR menggunakan metode analisis isi (content analysis) yaitu suatu metode pengkodifikasian teks dengan ciri - ciri yang sama ditulis dalam berbagai kelompok atau kategori berdasar pada kinerja yang ditentukan (Weber, 1988 dalam Sembiring, 2005). Nilai 1 jika item I diungkapkan, nilai 0 jika item I tidak diungkapkan, dengan demikian $0 \leq \mathrm{CSRIj} \leq 1$.

\subsection{Teknik Analisis Data}

Teknik analisis data yang digunakan dalam penelitian ini menggunakan pendekatan Partial Least Square (PLS) dengan menggunakan solfware Smart PLS. Menurut Ghozali (2006), PLS merupakan pendekatan alternatif yang bergeser dari pendekatan SEM berbasis covariance menjadi berbasis varian. SEM yang berbasis covariance umumnya menguji kausalitas/teori sedangkan PLS lebih bersifat predictive model. Oleh karena PLS tidak mengasumsikan adanya distribusi tertentu untuk estimasi parameter, maka teknik parametrik untuk menguji signifikasi parameter tidak diperlukan (Chin, 1998).

Analisis pada PLS dilakukan dengan tiga tahap (Ghozali, 2006), yaitu:

\section{Analisis model pengukuran atau outer model:}

Analisis outer model dilakukan untuk memastikan bahwa measurement yang digunakan layak untuk dijadikan pengukuran (valid dan reliabel). Analisis outer model menspesifikasikan hubungan antar variabel laten dengan indikator-indikatornya, atau dapat dikatakan bahwa outer model mendefinisikan bagaimana setiap indikator berhubungan dengan variabel latennya. Uji yang dilakukan pada outer model adalah:

a. Convergent Validity. Nilai convergent validity adalah nilai loading faktor pada variabel laten dengan indikator-indikatornya. Nila loading factor yang diharapkan $>0.70$.

b. Discriminant Validity. Nilai ini merupakan nilai cross loading yang berguna untuk mengetahui apakah konstruk memiliki diskriminan yang memadai yaitu dengan cara membandingkan nilai loading pada konstruk yang dituju harus lebih besar dibandingkan dengan nilai loading dengan kosntruk yang lain.

c. Average Variance Extracted (AVE). Nilai AVE yang diharapkan $>0.50$.

d. Construct Reliability. Uji reliabilitas diperkuat dengan Cronbach Alpha, nilai yang diharapkan $>0.60$ untuk semua konstruk. 


\section{Analisis Pengukuranmodel struktural atau inner model (hipotesis model)}

Analisis inner model (analisis struktural model) dilakukan untuk memastikan bahwa model struktural yang dibangun robust dan akurat. Inner model merupakan model struktural untuk memprediksi hubungan kausalitas antar variabel latent. Melalui proses boostrapping, parameter uji T-statistic diperoleh untuk memprediksi adanya hubungan kausalitas. Model struktural (inner model) dievaluasi dengan melihat prosentase variance yang dijelaskan oleh nilai $\mathrm{R}^{2}$. Analisis atau evaluasi inner model dapat dilihat dari beberapa indikator yang meliputi:

a. Melihat nilai $t$ dari hasil boostraping, kalau nilai $t>1,96$ ( $\operatorname{sig}$ pada $5 \%$ )

b. Melihat koefisien regresi

c. Melihat $\mathrm{R}^{2}$

Didalam PLS untuk menguji goodnessfit model atau kesesuaian model seperti dalam regresi yang dlihat nilai $\mathrm{R}^{2}$ (koefisien determinasinya). Pada saat anda me-run PLS calculate maka anda akan mendapatkan nilai koefisien regresi dari hubungan antar variabel, sedangkan untuk melihat apakah koefieisn regresi ini signifikan atau tidak anda harus me-run pls bootstraping untuk mendapatkan nilai $\mathrm{T}$ statistik dan dibandingkan dengan tabel t untuk melihat signifikan atau tidak. Jadi pada output inner weight table anya dilihat nilai $\mathrm{T}$ untuk menentukan signifikansinya, sedang nilai koefisien regresi dipilih yg sama dengan saat me-run sebelum bootstraping.

Model evaluasi PLS berdasarkan pengukuran prediksi yang mempunyai sifat nonparametric. Model pengukuran atau outer model yang indicator refleksif dievaluasi dengan konvergen dan validasi diskriminan dari indikatornya dan composite reliability untuk blok indicator. Sedangkan outer model dengan formatif indikator dievaluasi berdasarkan pada substantive contennya yaitu dengan membandingkan besarnya relative weight dan melihat signifikansi dari ukuran weight tersebut. Model structural atau inner model dievaluasi dengan melihat nilai R2 untuk konstruk laten respon dan juga melihat besarnya koefisien jalur strukturalnya. Stabilitas dari estimasi ini dievaluasi dengan menggunakan statistic uji-t yang didapat dari prosedur bootstrapping. (Ghozali, 2006: 24)

Model struktural dievaluasi menggunakan R-square untuk konstruk dependen, StoneGeisser Q-square untuk predictive relevance dan uji t serta signifikansi dari koefisien parameter jalur srtuktural. (Gozali, 2006:26). Stone-Geisser Q-square dapat dituliskan dengan formula sebagai berikut:

$$
\mathrm{Q} 2=1-(1-R 21)(1-\mathrm{R} 22)(1-\mathrm{R} 23) \ldots .(1-\mathrm{R} 2 \mathrm{n})(\text { Jaya et.al, 2008,I-14) }
$$

Validnya suatu indikator dapat diketahui nilai loadingnya, untuk penelitian yang bersifat eksploratif 0,5 sampai 0,6 dianggap cukup (Chin, 1996; Pirouz, 2006). Reliabilitas adalah ukuran konsistensi internal dari indikator-indikator sebuah variabel bentukan yang menunjukkan derajat sampai dimana masing-masing indikator itu mengindikasikan sebuah variable bentukan yang umum. Dalam menghitung reliabilitas menggunakan composite (construk) reliability dengan cut off value adalah minimal 0,7. Namun untuk penelitian bersifat eksploratori, reliabilitas sedang adalah 0,5-0,6 telah cukup menjustifikasi hasil penelitian (Ferdinand, 2002: 192) ${ }^{1}$. 


\section{HASIL DAN PEMBAHASAN}

\subsection{Data Penelitian}

Dalam penelitian ini, perusahaan yang digunakan sebagai objek penelitian ditentukan dengan menggunakan metode purposive sampling dengan ketentuan sebagai berikut: perusahaan makanan dan minuman yang terdaftar di Bursa Efek Indonesia selama 2 periode yaitu 2014-2015, yang mengupload annual report dan laporan keuangan tahun di website Indonesian Capital Market Directory (ICMD) selama 2 tahun berturut-turut dan melaporkan kegiatan tanggung jawab sosialnya di annual reportnya. Berikut adalah nama perusahaan yang dijadikan sampel dalam penelitian ini:

\section{Tabel 1:}

No Kode Nama Perusahaan Persh

1. ADES Ades Waters Indonesia Tbk

2. AIMS PT AKBAR INDO MADKUR STIMEC

3. AISA Tiga Pilar SejahteraFood Tbk

4. CEKA Cahaya Kalbar Tbk

5. DLTA Delta Djakarta Tbk

6. FAST Fast Food Indonesia Tbk

7. INDF Indofood Sukses MaDKur Tbk

8. MLBI Multi Bintang Indonesia Tbk

9. MYOR Mayora Indah Tbk

10. PSDN Prasidha Aneka Niaga Tbk

11. PTSP Pioneerindo Gour ment Indo nesia Tbk

12. ROTI PT NIPPON INDOSARI CORPINDO, Tbk.

13. SKBM Sekar Bumi Tbk

14. SMAR SMART Tbk

15. STTP Siantar Top Tbk

16. TBLA Tunas Baru Lampung Tbk

17. ULTJ Ultra Jaya Milk Tbk

\section{Sumber: Data diolah}

Pengambilan sampel penelitian dilakukan dengan menggunakan metode purposive sampling yaitu menentukan sampe dengan kriteria tertentu sesuai dengan kenetuanadalah 17 perusahaan, yaitu :

Tabel 2: Sampel Penelitian

\begin{tabular}{|l|c|}
\hline \multicolumn{1}{|c|}{ Kriteria sampel } & $\mathbf{2 0 1 4}$ \\
\hline Perusahaan makanan dan minuman yang terdaftar di BEI & 21 \\
\hline $\begin{array}{l}\text { Perusahaan makanan minuman yang tidak lengkap } \\
\text { menerbitkan annual report tahun 2014-2015 }\end{array}$ & $(2)$ \\
\hline $\begin{array}{l}\text { Perusahaan makanan minuman yang tidak melaporkan } \\
\text { kegiatan tanggung jawab sosialnya periode 2014- 2015 }\end{array}$ & $(2)$ \\
\hline Total obyek penelitian & 17 \\
\hline
\end{tabular}

\section{Sumber: Data diolah}

Berikut gambaran sebaran nilai dari masing-masing variabel. 
Tabel 3 : Ukuran Perusahaan

\begin{tabular}{|c|c|r|r|r|c|}
\hline \multirow{2}{*}{ NO } & \multirow{2}{*}{ PERSH } & \multicolumn{5}{|c|}{ SIZE PERSH (TOTAL AKTIVA) } \\
\cline { 3 - 6 } & & \multicolumn{1}{c|}{$\mathbf{2 0 1 4}$} & \multicolumn{1}{c|}{$\mathbf{2 0 1 5}$} & LOG N (2014) & LOG N (2015) \\
\hline 1 & ADES & 502.990 .000 .000 & 653.224 .000 .000 & 26,94 & 27,21 \\
\hline 2 & AIMS & 23.182 .051 .100 & 20.936 .619 .066 & 23,87 & 23,76 \\
\hline 3 & AISA & 7.373 .868 .000 .000 & 9.060 .979 .000 .000 & 29,63 & 29,83 \\
\hline 4 & CEKA & 1.284 .150 .037 .341 & 1.485 .826 .210 .015 & 27,88 & 28,03 \\
\hline 5 & DLTA & 997.443 .000 .000 & 1.038 .322 .000 .000 & 27,63 & 27,67 \\
\hline 6 & FAST & 2.162 .634 .000 .000 & 2.310 .656 .000 .000 & 28,40 & 28,47 \\
\hline 7 & INDF & 86.077 .200 .000 .000 & 91.831 .500 .000 .000 & 32,09 & 32,15 \\
\hline 8 & MLBI & 2.231 .051 .000 .000 & 2.100 .853 .000 .000 & 28,43 & 28,37 \\
\hline 9 & MYOR & 10.297 .990 .000 .000 & 11.342 .716 .000 .000 & 29,96 & 30,06 \\
\hline 10 & PSDN & 622.508 .000 .000 & 620.399 .000 .000 & 27,16 & 27,15 \\
\hline 11 & PTSP & 294.420 .107 .000 & 288.118 .595 .000 & 26,41 & 26,39 \\
\hline 12 & ROTI & 2.142 .894 .000 .000 & 2.706 .324 .000 .000 & 28,39 & 28,63 \\
\hline 13 & SKBM & 653.000 .000 .000 & 764.500 .000 .000 & 27,20 & 27,36 \\
\hline 14 & SMAR & 21.293 .000 .000 .000 & 23.957 .000 .000 .000 & 30,69 & 30,81 \\
\hline 15 & STTP & 1.700 .204 .093 .895 & 1.919 .568 .037 .170 & 28,16 & 28,28 \\
\hline 16 & TBLA & 7.328 .400 .000 .000 & 9.283 .800 .000 .000 & 29,62 & 29,86 \\
\hline 17 & ULTJ & 2.918 .134 .278 .435 & 3.539 .990 .910 .248 & 28,70 & 28,89 \\
\hline
\end{tabular}

Sumber: Data diolah

Tabel 4: Return on Assets, Ukuran Dewan Direksi \& CSR Indeks

\begin{tabular}{|c|c|c|c|c|c|c|c|c|}
\hline \multirow{2}{*}{ NO } & \multirow{2}{*}{ PERSH } & \multicolumn{2}{|c|}{ ROA (\%) } & \multicolumn{3}{c|}{ UKURAN DEWAN } & \multicolumn{2}{c|}{ DIREKSI CSR INDEKS } \\
\cline { 3 - 9 } & & $\mathbf{2 0 1 4}$ & $\mathbf{2 0 1 5}$ & $\mathbf{2 0 1 4}$ & $\mathbf{2 0 1 5}$ & RATA2 & $\mathbf{2 0 1 4}$ & $\mathbf{2 0 1 5}$ \\
\hline 1 & ADES & 6,18 & 5,03 & 4 & 4 & 4 & 0,551282051 & 0,525641026 \\
\hline 2 & AIMS & $-8,6$ & $-10,34$ & 3 & 5 & 4 & 0,435897436 & 0,512820513 \\
\hline 3 & AISA & 5,12 & 4,12 & 6 & 8 & 7 & 0,948717949 & 0,91025641 \\
\hline 4 & CEKA & 3,19 & 7,17 & 5 & 5 & 5 & 0,423076923 & 0,525641026 \\
\hline 5 & DLTA & 28,33 & 18,34 & 3 & 3 & 3 & 0,897435897 & 0,923076923 \\
\hline 6 & FAST & 5,82 & 4,54 & 5 & 5 & 5 & 0,782051282 & 0,743589744 \\
\hline 7 & INDF & 6,4 & 4,2 & 8 & 8 & 8 & 0,961538462 & 0,948717949 \\
\hline 8 & MLBI & 35 & 23,65 & 7 & 7 & 7 & 0,974358974 & 0,858974359 \\
\hline 9 & MYOR & 4 & 11 & 5 & 5 & 5 & 0,794871795 & 0,91025641 \\
\hline 10 & PSDN & $-1,18$ & $-3,2$ & 6 & 6 & 6 & 0,384615385 & 0,435897436 \\
\hline 11 & PTSP & 7,3 & $-0,5$ & 3 & 3 & 3 & 0,666666667 & 0,576923077 \\
\hline 12 & ROTI & 8,8 & 10 & 3 & 3 & 3 & 0,897435897 & 0,974358974 \\
\hline 13 & SKBM & 13,15 & 5,28 & 3 & 3 & 3 & 0,923076923 & 0,974358974 \\
\hline 14 & SMAR & 6,9 & $-1,6$ & 8 & 8 & 8 & 0,91025641 & 0,923076923 \\
\hline 15 & STTP & 7,27 & 9,67 & 3 & 3 & 3 & 0,512820513 & 0,448717949 \\
\hline 16 & TBLA & 6 & 2,2 & 3 & 3 & 3 & 0,435897436 & 0,384615385 \\
\hline 17 & ULTJ & 12,81 & 19,57 & 3 & 3 & 3 & 0,897435897 & 0,935897436 \\
\hline
\end{tabular}

Sumber: Data diolah 


\subsection{Hasil Olah Data Dengan PLS}

Unidimensionalitas suatu konstruk dapat dievaluasi melalui model pengukuran (outer model) dengan menggunakan reliabilitas komposit (composite reliability) dan validitas konvergen (convergent validity) dengan mengkonstruksi variabel laten ke dalam diagram jalur. Dengan melakukan uji validitas dan realibilitas, penelitian ini juga menguji indikator-indikator yang layak untuk dilanjutkan dalam penelitian. Berdasarkan pendapat tersebut, pada penelitian ini dapat dikonstruksi diagram jalur dengan menggunakan bantuan software smartPLS versi 2.0 sedangkan untuk analisis data lebih lanjut digunakan software PLS-Graph versi 2.0 yang dikembangkan oleh Wyene Chin, adapun diagram jalur tersebut dapat digambarkan sebagai berikut :

\section{Model awal (Overall Model dari hasil running PLS)}

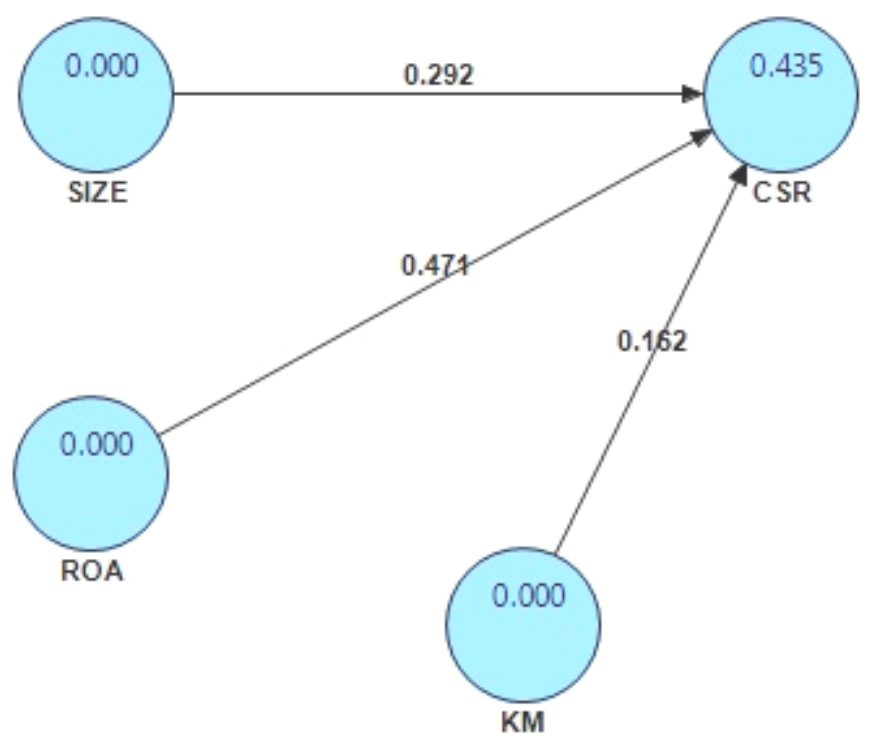

Gambar 1 Diagram Jalur Persamaan Struktural (hasil running PLS)

\section{Persamaan:}

CSR $=0.292 \mathrm{SIZE}+0.471 \mathrm{ROA}+0.162 \mathrm{DK}$

$\mathrm{R}$ square $=\mathbf{0 . 4 3 5}$ 
3. Hasil Uji t statistik Model dari hasil running PLS

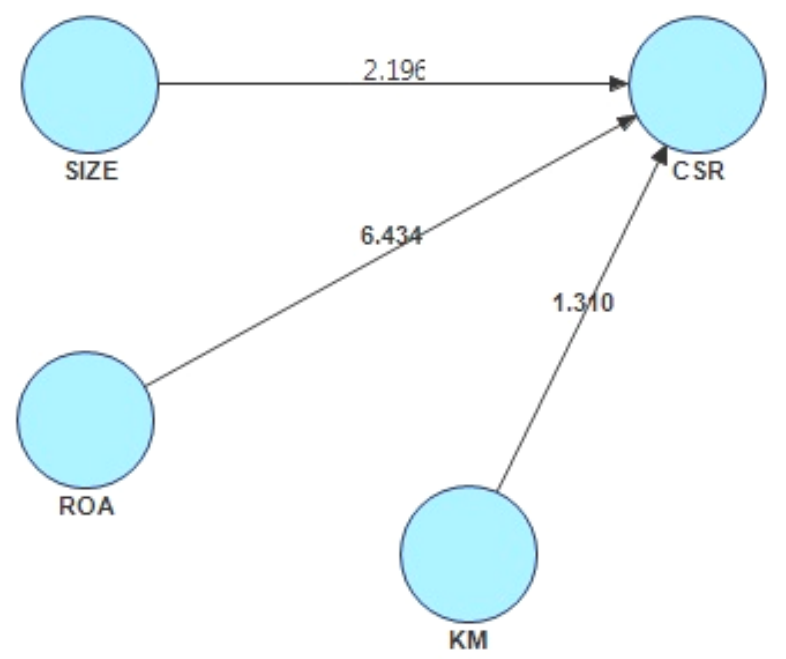

Gambar 2 Diagram Jalur Persamaan Struktural (Model dari hasil running PLS)

\section{Output PLS}

Inner Model T-Statistic

\begin{tabular}{|c|c|c|c|c|}
\hline & CSR & DK & ROA & SIZE \\
\hline CSR & & & & \\
\hline DK & 1.310 & & & \\
\hline ROA & 6.434 & & & \\
\hline SIZE & 2.196 & & & \\
\hline
\end{tabular}

Total Effects (Mean, STDEV, T-Values)

\begin{tabular}{|c|c|c|c|c|c|}
\hline & $\begin{array}{c}\text { Original } \\
\text { Sample } \\
(\mathbf{O})\end{array}$ & $\begin{array}{c}\text { Sample } \\
\text { Mean } \\
(\mathbf{M})\end{array}$ & $\begin{array}{c}\text { Standard } \\
\text { Deviation } \\
\text { (STDEV) }\end{array}$ & $\begin{array}{c}\text { Standard } \\
\text { Error } \\
\text { (STERR) }\end{array}$ & $\begin{array}{c}\text { T Statistics } \\
(\mid \mathbf{O} / \text { STERR|) }\end{array}$ \\
\hline $\begin{array}{c}\text { DK -> } \\
\text { CSR }\end{array}$ & 0.162 & 0.165 & 0.152 & 0.152 & 1.069 \\
\hline $\begin{array}{c}\text { ROA -> } \\
\text { CSR }\end{array}$ & 0.471 & 0.483 & 0.073 & 0.073 & 6.434 \\
\hline $\begin{array}{c}\text { SIZE -> } \\
\text { CSR }\end{array}$ & 0.292 & 0.294 & 0.136 & 0.136 & 2.148 \\
\hline
\end{tabular}

Outer Model T-Statistic

\begin{tabular}{|c|c|c|c|c|}
\hline & CSR & DK & ROA & SIZE \\
\hline CSR & & & & \\
\hline DK & & & & \\
\hline ROA & & & & \\
\hline SIZE & & & & \\
\hline
\end{tabular}


Path Coefficients (Mean, STDEV, T-Values)

\begin{tabular}{|c|c|c|c|c|c|}
\hline & $\begin{array}{c}\text { Original } \\
\text { Sample } \\
(\mathbf{O})\end{array}$ & $\begin{array}{c}\text { Sample } \\
\text { Mean } \\
(\mathbf{M})\end{array}$ & $\begin{array}{c}\text { Standard } \\
\text { Deviation } \\
(\text { STDEV) }\end{array}$ & $\begin{array}{c}\text { Standard } \\
\text { Error } \\
(\text { STERR) }\end{array}$ & $\begin{array}{c}\text { T Statistics } \\
(\mid \mathbf{O} / \text { STERR|) }\end{array}$ \\
\hline DK -> CSR & 0.162 & 0.187 & 0.124 & 0.124 & 1.310 \\
\hline ROA -> CSR & 0.471 & 0.483 & 0.073 & 0.073 & 6.434 \\
\hline SIZE -> CSR & 0.292 & 0.295 & 0.133 & 0.133 & 2.196 \\
\hline
\end{tabular}

Outer Weights (Mean, STDEV, T-Values)

\begin{tabular}{|c|c|c|c|c|c|}
\hline & $\begin{array}{c}\text { Original } \\
\text { Sample } \\
(\mathbf{O})\end{array}$ & $\begin{array}{c}\text { Sample } \\
\text { Mean } \\
(\mathbf{M})\end{array}$ & $\begin{array}{c}\text { Standard } \\
\text { Deviation } \\
\text { (STDEV) }\end{array}$ & $\begin{array}{c}\text { Standard } \\
\text { Error } \\
\text { (STERR) }\end{array}$ & $\begin{array}{c}\text { T Statistics } \\
(\mid \text { O/STERR|) }\end{array}$ \\
\hline CSR -> CSR & 1.000 & 1.000 & 0.000 & & \\
\hline DK -> DK & 1.000 & 1.000 & 0.000 & & \\
\hline ROA -> ROA & 1.000 & 1.000 & 0.000 & & \\
\hline SIZE -> SIZE & 1.000 & 1.000 & 0.000 & & \\
\hline
\end{tabular}

Outer Loadings (Mean, STDEV, T-Values)

\begin{tabular}{|c|c|c|c|c|c|}
\hline & $\begin{array}{c}\text { Original } \\
\text { Sample } \\
(\mathbf{O})\end{array}$ & $\begin{array}{c}\text { Sample } \\
\text { Mean } \\
(\mathbf{M})\end{array}$ & $\begin{array}{c}\text { Standard } \\
\text { Deviation } \\
\text { (STDEV) }\end{array}$ & $\begin{array}{c}\text { Standard } \\
\text { Error } \\
(\text { STERR) }\end{array}$ & $\begin{array}{c}\text { T Statistics } \\
(\mid \mathbf{O} / \text { STERR })\end{array}$ \\
\hline CSR -> CSR & 1.000 & 1.000 & 0.000 & & \\
\hline DK -> DK & 1.000 & 1.000 & 0.000 & & \\
\hline ROA -> ROA & 1.000 & 1.000 & 0.000 & & \\
\hline SIZE -> SIZE & 1.000 & 1.000 & 0.000 & & \\
\hline
\end{tabular}

Sumber: Data Diolah

\subsection{Pembahasan}

Berdasarkan analisis deskripfti terhadap perusahaan yang dijadikan sampel dalam penelitian ini menunjukkan bahwa rata-rata tingkat pengungkapan tanggung jawab sosial perusahaan yang diukur dengan menggunakan standar GRI tergolong dalam kategori sedang. Hal ini mengindikasikn bahwa tingkat pengungkapan tanggung jawab sosial perusahaan-perusahaan tersebut tergolong cukup baik.

Nilai koefisien path untuk pengaruh langsung antara DK terhadap CSR menunjukkan nilai $\mathrm{t}$ statistik sebesar 1.310 yang berada di bawah $\pm 1.96(5 \%)$, dengan demikian Ho diterima dan dapat disimpulkan bahwa terdapat pengaruh yang tidak signifikan antara jumlah Dewan Direksi terhadap CSR. Dengan nilai koefisien path sebesar 0.162 yang bernilai positif, dapat diartikan bahwa adanya peningkatan DK yang lebih banyak akan dapat meningkatkan CSR. Demikian sebaliknya. Namun, oleh karena hasil analisis data menunjukkan tidak ada hubungan yang signifikan, maka dapat dikatakan bahwa peningkatan maupun penurunan DK tidak mempengaruhi peningkatan maupun penurunan dari CSR. 
Nilai koefisien path untuk pengaruh langsung antara ROA terhadap CSR menunjukkan nilai t statistik sebesar 6.434 yang berada di atas \pm 1.96 (5\%), sehingga tolak Ho dan dapat disimpulkan bahwa terdapat pengaruh yang signifikan antara ROA terhadap CSR. Dengan nilai koefisien path sebesar 0.471 yang bernilai positif, dapat diartikan bahwa adanya peningkatan ROA yang lebih tinggi akan dapat meningkatkan CSR yang lebih tinggi pula. Demikian sebaliknya, jika ROA rendah, maka hal itu akan menyebabkan CSR ikut mengalami penurunan.

Nilai koefisien path untuk pengaruh langsung antara SIZE terhadap CSR menunjukkan nilai t statistik sebesar 2.196 yang berada di atas $\pm 1.96(5 \%)$, sehingga tolak Ho dan dapat disimpulkan bahwa terdapat pengaruh yang signifikan antara SIZE terhadap CSR. Dengan nilai koefisien path sebesar 0.292 yang bernilai positif, dapat diartikan bahwa adanya peningkatan SIZE yang lebih tinggi akan dapat meningkatkan CSR yang lebih tinggi pula. Demikian sebaliknya, jika SIZE rendah, maka hal itu akan menyebabkan CSR ikut mengalami penurunan.

\subsubsection{Uji Validitas Konvergen}

Untuk mengetahui apakah suatu indikator merupakan pembentuk konstrak (variabel laten) dilakukan pengujian validitas konvergen dari model pengukuran dengan indikator refleksif dinilai berdasarkan korelasi antara item score dengan construct score yang dihitung dengan bantuan software SmartPLS. Ukuran refleksif individual dikatakan valid jika memiliki korelasi (loading) dengan konstrak (variabel laten) yang ingin diukur $\geq 0,5$ atau nilai t-statistiknya harus $\geq 1.96$ (uji dua pihak) pada level signifikansi $\alpha=0,05$. Jika salah satu indikator memiliki nilai loading $<0,5$, atau nilai tstatistik < 1.96), maka indikator tersebut harus dibuang (didrop) karena mengindikasikan bahwa indikator tidak cukup baik untuk mengukur konstrak secara tepat. Ringkasan hasil pengujian validitas konvergen dengan menggunakan SmartPLS dapat dilihat pada tabel berikut.

Tabel 5. Uji validitas konvergen

\begin{tabular}{|c|c|c|c|c|c|c|}
\hline Variabel & $\begin{array}{c}\text { Original } \\
\text { Sample } \\
(\mathrm{O})\end{array}$ & $\begin{array}{c}\text { Sample } \\
\text { Mean } \\
(\mathrm{M})\end{array}$ & $\begin{array}{c}\text { Standard } \\
\text { Deviation } \\
(\text { STDEV })\end{array}$ & $\begin{array}{c}\text { Standard } \\
\text { Error } \\
(\text { STERR })\end{array}$ & $\begin{array}{c}\text { T Statistics } \\
(\mid \mathrm{O} / \text { STERR } \mid)\end{array}$ & Keterangan \\
\hline CSR -> CSR & 1.000 & 1.000 & 0.000 & & & Valid (Fix) \\
\hline DK -> DK & 1.000 & 1.000 & 0.000 & & & Valid (Fix) \\
\hline ROA -> ROA & 1.000 & 1.000 & 0.000 & & & Valid (Fix) \\
\hline SIZE -> SIZE & 1.000 & 1.000 & 0.000 & & & Valid (Fix) \\
\hline
\end{tabular}

\section{Sumber: Data Diolah}

Berdasarkan hasil pengujian validitas konvergen, dapat diketahui bahwa:

1. Indikator CSR dari variabel CSR memiliki nilai loading $>0,5$ yaitu sebesar 1.0, karena hanya ada 1 data yang mengukur variabel CSR tersebut, sehingga data variabel CSR valid secara fiksasi. Dengan demikian, maka data tersebut dapat diikutsertakan dalam pengujian lebih lanjut.

2. Indikator DK dari variabel DK memiliki nilai loading $>0,5$ yaitu sebesar 1.0, karena hanya ada 1 data yang mengukur variabel DK tersebut, sehingga data variabel DK valid secara fiksasi. Dengan demikian, maka data tersebut dapat diikutsertakan dalam pengujian lebih lanjut.

3. Indikator ROA dari variabel ROA memiliki nilai loading $>0,5$ yaitu sebesar 1.0, karena hanya ada 1 data yang mengukur variabel ROA tersebut, sehingga data 
variabel ROA valid secara fiksasi. Dengan demikian, maka data tersebut dapat diikutsertakan dalam pengujian lebih lanjut.

4. Indikator SIZE dari variabel SIZE memiliki nilai loading $>0,5$ yaitu sebesar 1.0, karena hanya ada 1 data yang mengukur variabel SIZE tersebut, sehingga data variabel SIZE valid secara fiksasi. Dengan demikian, maka data tersebut dapat diikutsertakan dalam pengujian lebih lanjut.

\subsubsection{Evaluasi Model}

1. Kriteria kualitas data

\begin{tabular}{|c|c|c|c|c|c|c|}
\hline & AVE & $\begin{array}{c}\text { Composite } \\
\text { Reliability }\end{array}$ & $\begin{array}{c}\text { R } \\
\text { Square }\end{array}$ & $\begin{array}{c}\text { Cronbachs } \\
\text { Alpha }\end{array}$ & Communality & Redundancy \\
\hline CSR & & & 0.435 & & 1.000 & 0.066 \\
\hline DK & & & & & 1.000 & \\
\hline ROA & & & & & 1.000 & \\
\hline SIZE & & & & & 1.000 & \\
\hline
\end{tabular}

Sumber: Data Diolah

- Contruct Reliability (sama dengan cronbach alpha mengukur reliabilitas konstruk atau variabel laten) nilainya hrs diatas 0.70 yang diangap reliabel. Namun untuk penelitian bersifat eksploratori, reliabilitas sedang adalah 0,5 - 0,6 telah cukup menjustifikasi hasil penelitian (Ferdinand, 2002: 192). Dari hasil pengujian di atas oleh karena menggunakan model formatif, sehingga tidak diperlukan nilai koefisien Cronbachs Alpha untuk menilai construct reliability setiap variabel.

- Composite reliability untuk blok indicator dari hasil pengujian PLS menunjukkan validasi model pengukuran atau outer model yang indicator refleksif. Sebab Validnya suatu indikator dapat diketahui nilai loadingnya, untuk penelitian yang bersifat eksploratif 0,5 sampai 0,6 dianggap cukup (Chin, 1996; Pirouz, 2006).

Dari hasil pengujian di atas oleh karena menggunakan model formatif, sehingga tidak diperlukan nilai Composite reliability untuk menilai validasi outer model setiap indicator dari variabel.

- Communalities pada dasarnya adalah jumlah varians (bisa dalam persentase) dari suatu variabel mula-mula yang bisa menjelaskan hasil analisis yang telah dilakukan. Untuk variabel CSR, DK, ROA, dan SIZE, semuanya mempunyai communalities sebesar 1.0 (paling tinggi), yang berarti $100 \%$ varians (keragaman) dari hasil analisis yang telah dilakukan bisa dijelaskan oleh variabel CSR, DK, ROA, dan SIZE.

2. Evaluasi Konstruk Variabel Dependen

- Evaluasi model menggunakan R-square $\left(\mathrm{R}^{2}\right)$ untuk konstruk dependen, Nilai $R$-square tersebut mencerminkan kekuatan prediksi dari keseluruhan model (Falk dan Miller, $1992^{2}$; Pirouz, 2006) dengan batasan nilai $R$-square lebih besar dari 0,10 atau lebih besar dari 10 persen (atau goodness-fit dari model).

Dari hasil analisis PLS di atas menunjukkan nilai R-square sbb: 


\begin{tabular}{|c|c|}
\hline & R Square \\
\hline CSR & 0.435 \\
\hline DK & \\
\hline ROA & \\
\hline SIZE & \\
\hline
\end{tabular}

yang berarti bahwa variabel ROA, SIZE dan DK mempunyai pengaruh terhadap CSR dengan kekuatan prediksi dari keseluruhan model sebesar 0.435 atau $43.5 \%$, sedangkan $56.5 \%$ dipengaruhi oleh faktor lain atau variabel yang tidak terdapat dalam model persamaan. Untuk DK, ROA, dan SIZE tidak mempunyai R square, karena variabel DK, ROA, dan SIZE tersebut merupakan variabel independen yang mempengaruhi variabel dependent, dalam kasus ini adalah CSR.

3. Evaluasi Predictive Relevance Stone-Geiser Q-Square test untuk predictive relevance. Dari nilai R2 selanjutnya dimasukkan ke dalam persamaan $Q$-square berikut:

$\mathrm{Q} 2=1-(1-R 21)(1-\mathrm{R} 22)(1-\mathrm{R} 23) \ldots(1-\mathrm{R} 2 \mathrm{n})$

$\mathrm{Q} 2=1-(1-0.435)=0.435$

Nilai Q-Square lebih besar dari 0 (nol) menunjukkan bahwa model mempunyai predictive relevance, sedangkan nilai Q-Square yang kurang dari 0 (nol) menunjukkan bahwa model kurang memiliki predictive relevance (Imam Gozali, 2006: 26). Hasil Q-Square dari SmartPLS diatas menunjukkan bahwa model mempunyai predictive relevance, karena mempunyai nilai 0.435 yang lebih besar dari 0 (nol) berarti model baik untuk digunakan.

4. Sedangkan evaluasi Stone-Geiser Q-Square (Q2 test) untuk predictive relevance menghasilkan nilai R square yang bernilai lebih besar dari 0 (nol), sehingga hal ini memberikan makna bahwa model struktural mempunyai predictive relevance yang tinggi.

\subsubsection{Pengujian Hipotesis}

Untuk menguji hipotesis yang diajukan yaitu variabel apa saja yang berpengaruh signifikan, dapat dilihat besarnya nilai t-statistiknya.

Path Coefficients (Mean, STDEV, T-Values)

Tabel 6:

\begin{tabular}{|c|c|c|c|c|c|c|c|}
\hline & $\begin{array}{c}\text { Origina } \\
1 \\
\text { Sample } \\
(\mathrm{O})\end{array}$ & $\begin{array}{c}\text { Sample } \\
\text { Mean } \\
(\mathrm{M})\end{array}$ & $\begin{array}{c}\text { Standard } \\
\text { Deviatio } \\
\mathrm{n} \\
(\mathrm{STDEV} \\
)\end{array}$ & $\begin{array}{c}\text { Standard } \\
\text { Error } \\
(\text { STERR })\end{array}$ & $\begin{array}{c}\text { T Statistics } \\
(|\mathrm{O} / \mathrm{STERR}| \\
)\end{array}$ & $\begin{array}{c}\mathrm{T} \\
\text { tabel }\end{array}$ & Keputusan \\
\hline $\begin{array}{c}\text { DK -> } \\
\text { CSR }\end{array}$ & 0.162 & 0.187 & 0.124 & 0.124 & 1.310 & $\begin{array}{c}1.96 \\
0\end{array}$ & $\begin{array}{c}\text { Tidak } \\
\text { signifikan }\end{array}$ \\
\hline $\begin{array}{c}\text { ROA -> } \\
\text { CSR }\end{array}$ & 0.471 & 0.483 & 0.073 & 0.073 & 6.434 & $\begin{array}{c}1.96 \\
0\end{array}$ & signifikan \\
\hline $\begin{array}{c}\text { SIZE -> } \\
\text { CSR }\end{array}$ & 0.292 & 0.295 & 0.133 & 0.133 & 2.196 & $\begin{array}{c}1.96 \\
0\end{array}$ & signifikan \\
\hline
\end{tabular}

Sumber: Data Diolah 


\section{Keterangan:}

Apabila nilai $\mathrm{t}$ berada pada rentang nilai $-\mathrm{t}$ tabel (1.96) dan $+\mathrm{t}$ tabel (1.96), maka hipotesis akan ditolak atau dengan kata lain menerima hipotesis nol (Ho).

Nilai koefisien path untuk pengaruh langsung antara DK terhadap CSR menunjukkan nilai $t$ statistik sebesar 1.310 yang berada di bawah $\pm 1.96(5 \%)$, sehingga terima Ho dan dapat disimpulkan bahwa terdapat pengaruh yang tidak signifikan antara jumlah Dewan Direksi terhadap CSR. Dengan nilai koefisien path sebesar 0.162 yang bernilai positif, dapat diartikan bahwa adanya peningkatan DK yang lebih banyak akan dapat meningkatkan CSR. Demikian sebaliknya. Namun, oleh karena hasil analisa data menunjukkan tidak ada hubungan yang signifikan, maka dapat dikatakan bahwa peningkatan maupun penurunan DK tidak mempengaruhi peningkatan maupun penurunan dari CSR. Hasil dari uji parsial yang telah dilakukan menunjukkan bahwa ukuran dewan komisaris tidak berpengaruh signifikan terhadap pengungkapan tanggung jawab sosial yang berarti H5 ditolak. Berdasarkan data yang diperoleh, jumlah dewan komisaris pada perusahaan manufaktur sektor makanan dan minuman di BEI rata-rata hanya berjumlah 3 orang, sehingga dewan komisaris kurang dapat menjalankan fungsinya dengan baik dalam mengawasi atau memonitoring manajemen dalam mengelola perusahaan.

Berdasarkan teori stakeholders, dewan komisaris dianggap sebagai mekanisme pengendalian intern tertinggi, yang bertanggung jawab untuk memonitor tindakan manajemen puncak. Dikaitkan dengan pengungkapan informasi oleh perusahaan, kebanyakan penelitian menunjukkan adanya hubungan positif antara berbagai karakteristik dewan komisaris dengan tingkat pengungkapan informasi oleh perusahaan (Sembiring, 2005). Jika semakin banyak jumlah anggota dewan komisaris, maka akan semakin mudah untuk mengendalikan CEO dan monitoring yang dilakukan akan semakin efektif.

Dikaitkan dengan pengungkapan tanggung jawab sosial, maka tekanan terhadap manajemen juga akan semakin besar untuk mengungkapkannya. Hasil penelitian ini tidak berhasil mendukung teori agensi dan bertentangan dengan penelitian Sembiring (2005) dan Sulastini (2007) yang menyatakan bahwa semakin besar anggota dewan komisaris, maka semakin besar kemungkinan perusahaan akan mengungkapkan tanggung jawab sosialnya. Berdasarkan data yang diperoleh jumlah dewan komisaris pada Perusahaan Manufaktur di BEIhanya 3 orang, sehingga dewan komisaris kurang dapat menjalankan fungsinya dengan baik dalam mengawasi atau memonitoring manajemen dalam mengelola perusahaan.Kecilnya nilai ukuran dewan komisaris, sehingga nilai rata-rata yang dihasilkan rendah dan menjadi tidak berpengaruh.

Hasil penelitian ini tidak berbeda dengan hasil penelitian yang dilakukan oleh Nofandrilla (2008) yang menyatakan bahwa ukuran dewan komisaris tidak berpengaruh secara signifikan terhadap pengungkapan tanggung jawab sosial perusahaan. Sementara penelitian yang dilakukan oleh Sembiring (2005) maupun Beasly (2000) menyatakan bahwa semakin besar jumlah anggota dewan komisaris, maka akan semakin mudah untuk mengendalikan CEO dan pengawasan yang dilakukan akan semakin efektif. Dikaitkan dengan pengungkapan tanggung jawab sosial perusahaan, maka tekanan terhadap manajemen juga akan semakin besar untuk mengungkapkannya.

Nilai koefisien path untuk pengaruh langsung antara ROA terhadap CSR menunjukkan nilai $t$ statistik sebesar 6.434 yang berada di atas $\pm 1.96(5 \%)$, sehingga 
tolak Ho dan dapat disimpulkan bahwa terdapat pengaruh yang signifikan antara ROA terhadap CSR. Dengan nilai koefisien path sebesar 0.471 yang bernilai positif, dapat diartikan bahwa adanya peningkatan ROA yang lebih tinggi akan dapat meningkatkan CSR yang lebih tinggi pula. Demikian sebaliknya, jika ROA rendah, maka hal itu akan menyebabkan CSR ikut mengalami penurunan.

Nilai koefisien path untuk pengaruh langsung antara SIZE terhadap CSR menunjukkan nilai t statistik sebesar 2.196 yang berada di atas \pm 1.96 (5\%), sehingga tolak Ho dan dapat disimpulkan bahwa terdapat pengaruh yang signifikan antara SIZE terhadap CSR. Dengan nilai koefisien path sebesar 0.292 yang bernilai positif, dapat diartikan bahwa adanya peningkatan SIZE yang lebih tinggi akan dapat meningkatkan CSR yang lebih tinggi pula. Demikian sebaliknya, jika SIZE rendah, maka hal itu akan menyebabkan CSR ikut mengalami penurunan. Ukuran perusahaan merupakan variabel penduga yang banyak digunakan untuk menjelaskan variasi pengungkapan dalam laporan tahunan perusahaan. Hasil penelitian ini sejalan dengan penelitian yang dilakukan oleh Siregar dan Utama dalam Nofandrilla (2008) bahwa semakin besar ukuran perusahaan, informasi yang tersedia untuk investor dalam pengambilan keputusan sehubungan dengan investasi saham semakin banyak. Sembiring (2005) dan Nofandrilla (2008) menemukan pengaruh yang signifikan ukuran perusahaan terhadap pengungkapan tanggung jawab sosial perusahaan. Namun, hal ini tidak sejalan dengan hasil penelitian yang dilakukan oleh Anggraini (2006) dan Roberts (1992) yang menyatakan bahwa ukuran perusahaantidak berpengaruh terhadap pengungkapan tanggung jawab sosial perusahaan.

Statistics

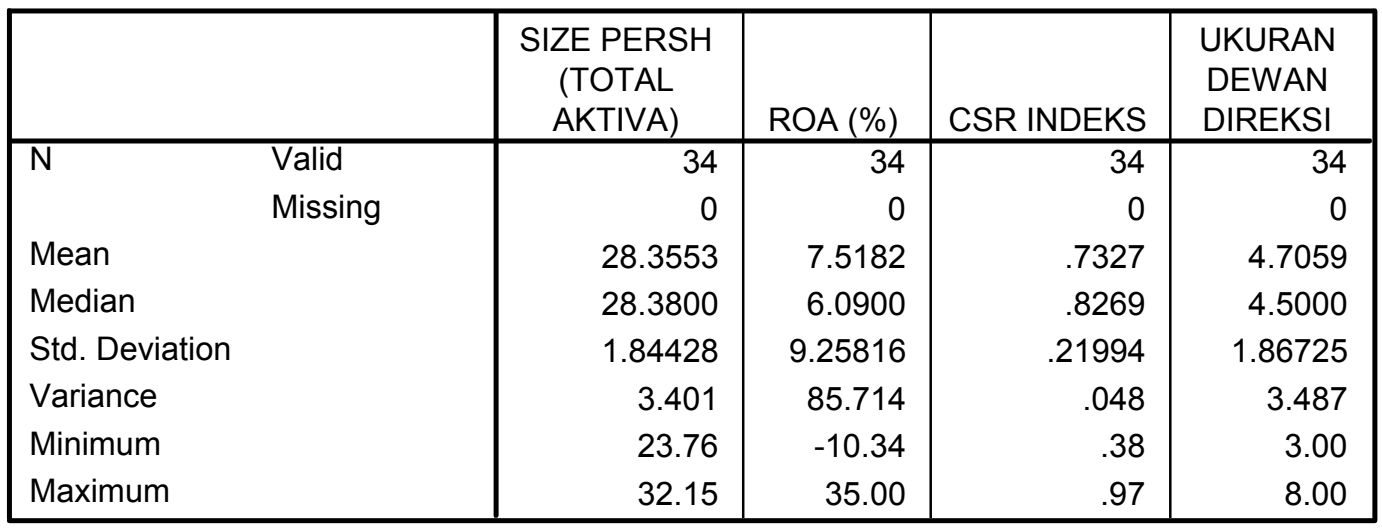

\section{SIMPULAN DAN SARAN}

\subsection{Simpulan}

Dari hasil analisis dapat disimpulkan bahwa terdapat pengaruh yang signifikan antara SIZE terhadap CSR. Dengan nilai koefisien path sebesar 0.292 yang bernilai positif, dapat diartikan bahwa adanya peningkatan SIZE yang lebih tinggi akan dapat meningkatkan CSR yang lebih tinggi pula. Demikian sebaliknya, jika SIZE rendah, maka hal itu akan menyebabkan CSR ikut mengalami penurunan. Mengungkapkan lebih banyak informasi merupakan bagian dari upaya perusahaan untuk mewujudkan akuntabilitas publik. Oleh karena itu, pengaruh ukuran perusahaan sesuai dengan teori yaitu semakin besar ukuran perusahaan maka perusahaan semakin banyak mengungkapkan tanggung jawab sosialnya. 
Hasil penelitian ini sejalan dengan hasil peneliti terdahulu yang menunjukkan bahwa semakin besar ukuran suatu perusahaan semakin banyak informasi sukarela yang diungkapkan dalam laporan tahunan. Variabel ukuran perusahaan merupakan variabel yang paling konsisten berpengaruh signifikan terhadap pengungkapan tanggung jawab sosial dalam penelitian-penelitian sebelumnya, yaitu penelitian yang dilakukan Almilia (2008), Amalia (2005) dan Sembiring (2005).

Sementara itu terdapat pengaruh yang positip signifikan antara ROA terhadap CSR. Dengan nilai koefisien path sebesar positip 0.471, dapat diartikan bahwa adanya peningkatan ROA yang lebih tinggi akan dapat meningkatkan CSR yang lebih tinggi pula. Demikian sebaliknya, jika ROA rendah, maka hal itu akan menyebabkan CSR ikut mengalami penurunan. Perusahaan dengan berita baik akan berusaha menyampaikan informasi yang berkaitan dengan berita baik tersebut ke pasar dalam bentuk pengungkapan sukarela yang lebih lengkap atau banyak dalam laporan tahunan untuk memberikan dampak yang positif terhadap nilai perusahaan. Jika pengungkapan berita baik itu tidak dilakukan, pasar akan menerjemahkannya sebagai berita buruk sehingga berdampak pada penilaian perusahaan yang terlalu rendah (Amalia, 2005). Perusahaan cenderung melakukan pengungkapan tanggung jawab sosial untuk memberikan legitimasi aktivitasnya agar mendapat nilai tambah dari masyarakat. Apabila profitabilitas perusahaan menunjukkan suatu peningkatan, maka hal itu merupakan suatu berita baik bagi perusahaan tersebut.

Disisi yang lain, terdapat pengaruh yang tidak signifikan antara jumlah Dewan Direksi terhadap CSR. Dengan nilai koefisien path sebesar 0.162 yang bernilai positif, dapat diartikan bahwa adanya peningkatan DK yang lebih banyak akan dapat meningkatkan CSR. Demikian sebaliknya. Namun, oleh karena hasil analisis data menunjukkan tidak ada hubungan yang signifikan, maka dapat dikatakan bahwa peningkatan maupun penurunan DK tidak mempengaruhi peningkatan maupun penurunan dari CSR.

\subsection{Saran}

Beberapa saran yang dapat diusulkan terkait dengan hasil penelitian ini diantaranya adalah sebagai berikut:

1. Menggunakan sampel yang lebih besar dengan mengambil sampel lebih dari tiga tahun dan dapat meneliti pada sampel seluruh perbankan di Indonesia sehingga dapat dievaluasi kinerja modal intelektual secara keseluruhan.

2. Menambah variabel kinerja keuangan perusahaan dilihat dari sisi rasio rentabilitas yang lain yaitu dapat diukur dengan Gross Profit Margin dan Net Profit Margin. Ini menunjukkan kemampuan perusahaan dalam menghasilkan laba operasi usahanya yang murni dan laba bersih ditinjau dari pendapatan operasinya. Sehingga dapat diketahui bagaimana kinerja keuangan perusahaan makanan dan minuman dari sisi rasio rentabilitas secara keseluruhan.

3. Analisis data merupakan salah satu hal terpenting dalam pengambilan kesimpulan. Kesalahan prosedur dalam melakukan analisa data bisa berakibat sangat fatal terhadap kesimpulan yang diambil, yaitu hasil kesimpulan yang diperoleh akan menyimpang (berbias/ tidak sesuai) dengan kenyataan yang sebenarnya. Sehingga hanya akan menghasilkan suatu kesimpulan yang tidak sahih/ tidak valid atau dengan kata lain tidak dapat dipertanggungjawabkan kebenarannya. Oleh sebab itu sebelum dilakukan running data, pastikan bahwa data harus diperiksa (untuk melihat adanya pencilan atau tidak, penghitungan terhadap data hilang (missing 
value analysis), uji normalitas data, dll), validitas data, dll, hingga analisis statistika yang sesuai dengan tujuan yang diharapkan.

\section{DAFTAR PUSTAKA}

Abidin (2000), Pelaporan MI:"Upaya Mengembangkan Ukuran-ukuran Baru”, Media Akuntansi, Edisi 7, Thn. VIII, pp. 46-47

Balabanis, George, Phillips, Hugh C., Lyall, Jonathan, (1998) "Corporate Social Responsibility \& Economic Performance in the Top British Companies: Are They Linked?” European Business Review, Vol. 98, No.1, pp. 25-44, available online: www.citeseerx.ist.psu.edu (accessed January 2015)

Chin, W.W, Marcolin,B.L dan Newsted, P.R.1996. A Partial Least Squares Laten Variabel Modeling Approach for Measuring Interaction Efects: Results From A Monte Carlo Simulation Study And Voice Mail Emotion/Adoption Study. Proceedings Of The Seventeenth International Conference On Information Systems. December 16-18. Cleveland. Ohio.

Dahlia, Lely dan S. V. Siregar, (2008)."Pengaruh Corporate Social Responsibility Terhadap Kinerja Perusahaan (Studi Empiris Pada Perusahaan Yang Tercatat Di Bursa Efek Indonesia Pada Tahun". Simposium Nasional Akuntansi XI: Pontianak, 23-25 Juli 2008.

Darwin, Ali. (2004). Penerapan Sustainability Reporting di Indonesia. Konvensi Nasional Akuntansi V, Program Profesi Lanjutan. Yogyakarta, 13-15 Desember. .(2006) "Sustainbility Reporting/ Laporan Keberlanjutan". Makalah disajikan pada kuliah perdana di Banda Aceh: Jurusan Akuntansi Fakultas Ekonomi Unsyiah, 1 September 2006

Elkington, John. 1997. Cannibals with Forks.The Triple Bottom Line of the 21stCentury. Oxford: Capstone

Finch, Nigel, (2005) “The Motivations for Adopting Sustainability Disclosure", MGSM Working Papers in Management, Macquarie University, Australia. available online: www.papers.ssrn.com (accessed January 2009)

Freeman, R.Edward \& Reed, David L.1983). "Stockholders and Stakeholders: A New Perspectiveon Corporate Governance,California Management Review, Vol.XXV, No.3, Spring

Ghozali, Imam (2001) "Aplikasi Analisis Multivariate dengan Program SPSS". Semarang: Universitas Diponegoro.

Ghozali, Imam. 2006. Structural Equaation Modeling Metode Alternatif Dengan Partial Least Square (PLS). Badan Penerbit Universitas Diponegoro. Semarang.

Jaya, IGNM et al. 2008. Partial Least Square-Mixed Ammi Dalam Analisis Interaksi Genotipe X Lingkungan. Prosiding Seminar Nasional Sains dan Teknologi-II 2008 Universitas Lampung. Lampung.

Pirouz, Dante, M. 2006. An Overview of Partial Least Squares. The Paul MerageSchool of Business University of California. IrvineHarahap, Syafri S (2002). Teori Akuntansi. Edisi Revisi. Jakarta: PT. Raja Gravindo Persada. Jakarta (2004). Analisis Kritis atas Laporan Keuangan. PT. Raja Grafindo Persada. Jakarta

Suharto, Edi (2006), "Pekerjaan Sosial di Dunia Industri, CSR dan ComDev". Disampaikan pada Workshop tentang Corporate Social Responsibility, LSPSTKS Bandung. 
Wibisono, Yusuf. (2007), "Membedah Konsep dan Aplikasi Corporate Social Responsibility", Fascho Publishing, Gresik 